\title{
5. The European Semester: understanding an innovative governance model
}

\author{
Sonja Bekker
}

\section{INTRODUCTION}

This chapter gives an overview of the European Semester (hereafter Semester). On the one hand, it maps out the history, elements and functioning of the Semester. On the other hand, it indicates how the Semester can be studied and understood. Apart from the legal aspects underpinning the coordination methods of the Semester, politics are relevant as well, as the Semester allows for exchanges between actors across governance levels. It makes the Semester a dynamic process with annually recurring governance processes and the ability to adapt both its content and procedures.

Two key events may explain the design and implementation of the Semester in 2011. The first is the end of the Lisbon Strategy (2000-2010) and the ambition to make the subsequent Europe 2020 Strategy more successful. ${ }^{1}$ The second is the severe financial and economic crisis which started plaguing Europe in 2008. In the economic field, the Stability and Growth Pact rules should have kept Member States financially and economically healthy. However, in reality it had too little impact in terms of Member State compliance with the rules of maximum debt and expenditure. ${ }^{2}$ Therefore, EU leaders urged the strengthening of EU economic governance. This urgency was fed by the severity of the financial and economic crisis, which moreover demonstrated the interdependence of Member States. The financial instability of one country seemed to spill over easily to other countries. The idea behind stricter economic governance was increasing Member State compliance by strengthening already existing coordination cycles, and by implementing new coordination cycles. Additionally, all these coordination cycles, ranging from social to economic issues, have been placed within one framework: the European Semester.

On the one hand, the Semester is nothing more than a period of about nine months in which all EU socio-economic coordination activities occur. It brings together existing EU socio-economic coordination cycles and builds on the rich knowledge the EU gained in decades of policy coordination. One example is the European Employment Strategy, which has been running since 1997. It is now part of the

1 C de la Porte and E Heins, 'A New Era of European Integration? Governance of Labour Market and Social Policy Since the Sovereign Debt Crisis' (2015) 13(1) Comparative European Politics 8.

${ }_{2}$ I Begg, 'Fiscal and Other Rules in EU Economic Governance: Helpful, Largely Irrelevant or Unenforceable?' (2017) 239(1) National Institute Economic Review 3. 
Europe 2020 Strategy. Also the Stability and Growth Pact has been running since 1997 and became part of the Semester in 2011. A third coordination mechanism is the newly created Macroeconomic Imbalances Procedure (MIP), ${ }^{3}$ which was implemented in 2011. On the other hand, we could see the Semester as a major step in EU governance. ${ }^{4}$ To understand why the Semester is an example of coordination innovation, but also to understand the pathway towards the implementation of the Semester, the next section describes the history of EU socio-economic coordination prior to the Semester.

\section{THE HISTORY AND CONTEXT OF THE EUROPEAN SEMESTER}

\subsection{Employment and Social Policy Coordination}

The European Employment Strategy was installed after an extraordinary European Council on Employment (the 'Jobs Summit') in Luxembourg in 1997..$^{5}$ This annual process of employment policy monitoring has been anchored in the Treaty since the Treaty of Amsterdam 1998 (now Article 148 Treaty on the Functioning of the European Union - TFEU). It was the result of a decade of discussing the employment topic at the EU level, driven by concerns about the labour market effects of globalisation, technological developments and the ageing of society. ${ }^{6}$ The employment strategy is a cycle that starts out with setting goals in employment guidelines which are proposed by the Commission, agreed by national governments and adopted by the European Council. Next, the Commission publishes (and the Council endorses) a Joint Employment Report which monitors European labour markets and the progress of countries, including by assessing the implementation of the employment guidelines. After 2013, the monitoring started including a scoreboard of social indicators as well. Next, Member States submit a national reform programme with national reforms taken to meet the goals, and the Commission analyses these reports. Based on all these assessments, the Commission makes specific evaluations of each country and drafts country-specific recommendations which are endorsed by the Council. These country-specific recommendations fit the particular challenges of a country and are non-binding (or 'soft'). The choice for soft coordination fits the

\footnotetext{
3 S Bekker and S Klosse, 'EU Governance of Economic and Social Policies: Chances and Challenges for Social Europe' (2013) 2 European Journal of Social Law 103.

4 A Verdun and J Zeitlin, 'Introduction: The European Semester as a New Architecture of EU Socioeconomic Governance in Theory and Practice' (2018) 25(2) Journal of European Public Policy 137.

5 J Goetschy, 'The European Employment Strategy: Genesis and Development' (1999) 5(2) European Journal of Industrial Relations 117.

6 European Commission, 'Growth, competitiveness, employment. The challenges and ways forward into the 21st century' (1993) COM(93) 700 final.
} 
ideas about the employment and social policy coordination that have existed from the outset. They are seen as domestic issues on which the electorates of the Member States democratically decide.

The Lisbon Strategy (2000-2010) incorporated the employment policy coordination, but also set additional targets with the aim of making the EU into 'the most competitive and dynamic knowledge-based economy in the world'. It included four priorities (pillars), these being entrepreneurship, employability, adaptability and equal opportunities. ${ }^{7}$ The Lisbon Strategy was soon seen as quite an innovative form of governance because of its ability to set one EU-level target, while leaving it up to the Member State to design and implement specific employment policies to meet these EU-level goals. ${ }^{8}$ It thus was a way to address common challenges, while keeping in mind national diversity and autonomy. In addition, the Lisbon Strategy combined these sets of policy tools and regulations with social dialogue and the use of structural funds, such as the European Social Fund. ${ }^{9}$ This particular means of employment policy coordination, or coordination-based governance, would soon be referred to as the Open Method of Coordination (OMC). It has attracted much scholarly attention, for instance stimulating research on 'soft law' and experimentalist governance. ${ }^{10}$ Important elements of the OMC include experimentation and knowledge sharing, flexibility and adjustment of goals and guidance, and diversity and decentralisation of policy making. ${ }^{11}$ New EU-level bodies were developed as well as part of this coordination process. The Employment Committee (EMCO) (created in 2000, on the basis of Article 150 TFEU), for instance, operates within the policy framework of the employment strategy and advises the Employment and Social Affairs Ministers in the Employment and Social Affairs Council (EPSCO) on employment issues. In the same period a social OMC was created in the field of social protection and social inclusion. Here, the Social Protection Committee (SPC) advises Employment and Social Affairs Ministers in the EPSCO Council. The employment OMC is seen as the most developed example of the OMC. ${ }^{12}$

Goetschy (n 5).

8 D Natali, 'The Lisbon Strategy, Europe 2020 and the Crisis in Between' (2010) European Social Observatory (OSE) Paper Series No 4/31, www.ose.be/files/publication/ 2010/Natali_2010_Lisbon\%20StrategyEU2020\&Crisis.pdf, accessed 21 October 2019.

9 Ibid.

10 For example, J Zeitlin and P Pochet (eds), with L Magnusson, The Open Method of Co-ordination in Action: The European Employment and Social Inclusion Strategies (Peter Lang 2015); KA Armstrong, Governing Social Inclusion: Europeanization through Policy Coordination (Oxford University Press 2014); CF Sabel and J Zeitlin, Experimentalist Governance in the European Union: Towards a New Architecture (Oxford University Press 2010).

${ }_{11}$ See Natali (n 8); J Scott and D Trubek, 'Mind the Gap: Law and New Approaches to Governance in the European Union' (2002) 8(1) European Law Journal 1; A Héritier, 'New Modes of Governance in Europe: Policy-Making without Legislating?' in A Héritier (ed), Common Goods: Reinventing European and International Governance (Rowman \& Littlefield Publishers 2002).

12 Zeitlin, Pochet and Magnusson (n 10). 
The Lisbon Strategy demonstrated that employment policy coordination is not a static process. It has the ability to develop and adapt. The first adjustments have been made only a few years after the implementation of the Lisbon Strategy. A large driver for this was the deterioration of the economic climate (the burst of the Internet bubble around 2000), while the upcoming enlargement of the EU made it ever more relevant to turn the ambitions of the Lisbon Strategy into results. As the chair of an Employment Taskforce and a high level group, the former Dutch Prime Minister Kok wrote two quite influential reports, focusing on job creation and a better running strategy ('Jobs, jobs, jobs; creating more employment in Europe' (November 2003) and 'Facing the challenge; The Lisbon strategy for growth and employment' (November 2004). ${ }^{13}$ The main messages were more jobs, more adaptability and more investment in human resources. Moreover, the reports suggested a focus on priorities (thus fewer goals and targets) and a focus on implementation. ${ }^{14}$

In the end, the Lisbon Strategy failed to reach most of its goals, although some countries did well on a number of the goals. Other goals might have been too ambitious, and the economic slow-down during some of the years of the Lisbon Strategy posed additional obstacles to meeting goals. Currently, the Europe 2020 Strategy is running as the follow-up strategy to Lisbon. It is an agenda for growth and jobs, aiming at smart, sustainable and inclusive growth. It has quantitative targets on employment, education, research and development, limiting poverty and social exclusion, and improving the environment. The coordination cycle of Europe 2020 is similar to that of the Lisbon Strategy. However, a major change is that employment and social policy coordination has become part of the Semester, joining them with economic and fiscal policy coordination.

\subsection{Economic and Fiscal Policy Coordination}

EU economic and fiscal coordination have quite a similar history to employment and social policy coordination. Economic coordination started with the Treaty on European Union 1992, which paved the way for introducing a single currency. Limits were set for national debt (60 per cent of gross domestic product (GDP)) and budget deficit (3 per cent of GDP), thus preventing governments from spending too much. In order to monitor economic and fiscal developments of Member States, the Stability

13 European Commission and W Kok 'Jobs, jobs, jobs: Creating more employment in Europe' (2003) Report of the Employment Taskforce, https://op.europa.eu/en/publication -detail/-/publication/eba3e718-ec56-4da4-8b01-0c9101c8d4ac, accessed 21 October 2019; High Level Group (chaired by W Kok), 'Facing the challenge: the Lisbon strategy for growth and employment' (2004) Report from the High Level Group chaired by Wim Kok, https://ec.europa.eu/research/evaluations/pdf/archive/fp6-evidence-base/evaluation _studies_and_reports/evaluation_studies_and_reports_2004/the_lisbon_strategy_for_growth _and_employment_report_from_the_high_level_group.pdf, accessed 21 October 2019; $\overline{\mathrm{M}}$ Mailand, Coalitions and Policy Coordination: Revision and Impact of the European Employment Strategy (Djøf Forlag 2006).

14 S Bekker, Flexicurity: The Emergence of a European Concept (Intersentia 2011). 
and Growth Pact (SGP) was introduced (1997). ${ }^{15}$ Similar to the employment strategy, it has a set of guidelines that offer qualitative guidance to Member State reforms. These guidelines are called the Broad Economic Policy Guidelines. In 2010 a first integration of these economic policy guidelines happened, when they were joined together with the employment guidelines into one list of Integrated Guidelines. ${ }^{16}$

The SGP process is quite similar to that of the employment strategy. One key difference is that the SGP has both a preventative arm and a corrective arm. This means that Euro area countries that perpetually fail to observe the debt and deficit limits may become subject to enforced surveillance, possibly ending in a financial penalty. Also the SGP has been subject to changes. An important event leading to such changes was the breaches of France and Germany of the SGP in 2003. ${ }^{17}$ The Commission proposed to impose penalties, however this proposal did not lead to a Council decision to apply such penalties. ${ }^{18}$ This inability to impose fines sparked questions on the purpose and effectiveness of the SGP. In 2005, decisions led to more flexibility in the rules, including setting conditions under which the Member States may exceed the 3 per cent deficit level. This gave Member States more flexibility to develop policies to meet their individual economic circumstances, for instance by pursuing a strategy of public investments. ${ }^{19}$

Conversely, the economic crisis of 2008 was a reason to enforce surveillance, via the Six-Pack Regulations (2011), the Fiscal Compact and Two-Pack Regulations (2013). ${ }^{20}$ Thus, the flexibility within the SGP was narrowed down by enhancing surveillance. For instance, the Six-Pack changed the voting procedure into reverse qualified majority voting, which means that a recommendation by the Commission is deemed to be adopted unless the Council decides by qualified majority to reject this recommendation. This makes it more difficult to form blocking minorities in the Council. ${ }^{21}$ The adoption of the intergovernmental Treaty on Stability, Coordination and Governance of EMU (TSCG or the Fiscal Compact of 2013), moreover, has committed Euro area countries to integrate the core principles of the SGP in their national legal frameworks through provisions of binding force and of a permanent character. ${ }^{22}$ The Two-Pack of 2013 defined additional steps, extending the Commission's power to review Eurozone countries' draft budgetary plans and to

15 Articles 121 and 126 TFEU.

16 Bekker and Klosse (n 3).

17 Begg (n 2).

18 JD Savage and A Verdun, 'Reforming Europe's Stability and Growth Pact: Lessons from the American Experience in Macrobudgeting' (2007) 14(5) Review of International Political Economy 842.

19 S Bekker, 'The EU's Stricter Economic Governance: A Step Towards More Binding Coordination of Social Policies?' (2013) Wissenschaftszentrum Berlin für Sozialforschung Discussion Paper SP IV 2013-501.

20 A Hinarejos, 'Fiscal Federalism in the European Union: Evolution and Future Choices for EMU' (2013) 50 Common Market Law Review 1621.

${ }^{21}$ Bekker and Klosse (n 3).

22 Ibid. 
request a new draft budget if there is a risk of failure to meet the SGP rules. So far, the Council has decided only twice that countries had not taken effective action to bring down debts and deficits: Portugal and Spain in 2016. ${ }^{23}$ However, the decision was quite symbolic as the Council decided to cancel the fine. ${ }^{24}$

In addition to stricter economic governance via the SGP, the Six-Pack introduced the MIP in 2011. Its purpose is to detect and correct imbalances in the economy at a very early stage, thus taking a preventative approach. Similar to the SGP, the MIP has a preventative and a corrective arm and it is also part of the Semester. The MIP has an alert mechanism that uses a scoreboard of indicators which measures Member States' performances. Each November the overall scores of Member States are published in an alert mechanism report. If the Commission witnesses adverse trends in statistics, it undertakes a more thorough and comprehensive analysis of the country, called an in-depth review (which is part of the country reports). If this concludes that there are possibly problematic macroeconomic imbalances that require corrective action, the procedure proceeds in more or less the same way as the SGP. It goes from a preventative to a corrective stage: the excessive imbalances procedure. In this stage of the MIP, countries may receive country-specific recommendations. If the imbalances are severe, the country's policy commitments will be monitored through specific monitoring, which includes dialogue with the national government as well as progress reports. Eventually, if there is no progress, Euro area countries risk having to make an interest-bearing deposit, which eventually may be converted into a fine. ${ }^{25}$ Here also, the reverse majority voting rule applies.

Thus, for understanding the Semester, it is relevant to know that it hosts several coordination mechanisms, some of which have existed since 1997. There is a tradition of coordination-based and rule-based governance and these have been adjusted occasionally in order to meet new challenges. What makes the Semester especially interesting is the increased interconnectedness of the separate coordination cycles, as well as the dynamics of actor interaction at key moments in the governance process. Such ingredients and operation are explained below.

\section{THE EUROPEAN SEMESTER: INGREDIENTS AND OPERATION}

The ability of the separate employment, social, fiscal and economic coordination cycles to adjust to country-specific situations and to account for new social and eco-

23 Council Implementing Decisions (EU) 2017/2350 and 2017/2351 of 9 August 2016 on imposing a fine on Portugal and Spain for failure to take effective action to address an excessive deficit.

${ }^{24}$ De la Porte and Heins (n 1); C de la Porte and E Heins, 'The Aftermath of the Eurozone Crisis: Towards Fiscal Federalism?' in D Dinan, W Paterson and N Nugent (eds), The EU, Public Policy and the Crises (Palgrave Macmillan 2017).

25 Ibid, 107. 
nomic developments has remained part of their characteristics after their inclusion in the Semester. ${ }^{26}$ The Semester now includes employment and social policy coordination, the SGP and the MIP. The existing coordination cycles have remained the same in terms of the coordination activities they hold each year. Thus, the Semester provides a framework for the annual coordination of financial, economic, employment and social policies across the European Union. It allows EU countries to discuss their plans on the broad socio-economic policy domain, and monitor progress at specific times throughout the year. Originally the Semester was a six-month process but it has since expanded. It means that the main EU priorities are communicated earlier and it has given national governments more time to involve national stakeholders, such as parliaments and the social partners, in the discussion of national policy measures. ${ }^{27}$ After the publication of the recommendations in June, a 'national semester' starts with national policy design and implementation, (supposedly) responding to the recommendations. It should make the Semester less of a top-down process, encouraging interaction between the Commission and the Member States and increasing national ownership. ${ }^{28}$

Each year in November, the Semester starts with the publication of the 'autumn package' by the European Commission. This package includes short-term goals and priorities written down in the Annual Growth Survey. Moreover, it includes a range of monitoring and evaluation reports, with economic forecasts, an alert mechanism report identifying countries that might experience economic imbalances, and a draft Joint Employment Report with analyses of the employment and social situations of countries and related policy responses by national governments. Lastly, the Commission releases recommendations to the Euro area as a whole (thus not country specific), as well as an opinion on the draft budgetary plans of countries.

In the winter and early spring the Commission and national governments hold bilateral meetings. In February the Commission publishes a Country report of each Member State. These include broad and integral analyses of the country's economic, financial, labour market and social status. Here, the Commission also checks countries' follow-up of the country-specific recommendations of the previous coordination cycle. Then, in April, Member States hand in their National Reform Programmes (on social and economic policies) and their Stability or Convergence Programmes (on economic and fiscal policies). In these national reports governments describe new policies and future reform plans and how these respond to the EU-level targets and previous recommendations. In May the Commission proposes new country-specific recommendations, based on the Country reports, the information from the bilateral meetings, and the national reports. In June the Council discusses

26 S Bekker, 'The European Semester Process: Adaptability and Latitude in Support of the European Social Model' in F Vandenbroucke, C Barnard and G De Baere (eds), A European Social Union after the Crisis (Cambridge University Press 2017).

${ }^{27}$ C Alcidi and D Gros, 'How to Strengthen the European Semester?' (2017) CEPS Research Report No. 2017/15.

28 Ibid. 
these draft recommendations and may alter them, and finally the European Council endorses them. Next, the Commission expects countries to take action. In November the cycle starts again.

Apart from the different stages in the monitoring and evaluation process, the Semester includes a range of actors from national and EU levels. Some of these have already been mentioned above. In addition to that, the European Parliament is an actor as well, yet with a limited (although growing) role in the process. ${ }^{29}$ It holds dialogues on the Annual Growth Survey and the draft recommendations, and makes a resolution on the Annual Growth Survey and the Semester itself. The role of national parliaments seems rather limited, although showing variations across countries. ${ }^{30}$ Other actors are the social partners, both at the EU and at the national levels. As yet, their role seems to be limited, though their inclusion in the process has been improved and at least emphasised more after 2015. ${ }^{31}$

The process and ingredients as outlined above are relatively clear. The real complexity emerges when understanding the different coordination cycles and actors that are brought together within the Semester, combined with the Semester's ability to adapt to new demands and specific country settings. Thus, the Semester should be understood by the combination of its instruments, actors and flexible adjustment. These characteristics make the Semester, using the words of Verdun and Zeitlin, 'a prime example of the complexity that supersedes simple polar opposition'. ${ }^{32}$ Therefore, the Semester challenges the theoretical understandings of EU governance. These challenges evolve around three axes: the social-economic axis, the intergovernmental-supranational axis, and the technocratic-democratic axis. ${ }^{33}$ For the purpose of developing these theoretical elements later on in the chapter, we will first outline the effects of the inclusion of separate coordination cycles within the framework of the Semester. This will demonstrate how the joining together of instruments leads to a balancing act on all of the three axes.

29 A Verdun and J Zeitlin, 'The European Semester as a New Architecture of EU Socioeconomic Governance in Theory and Practice' (2018) 25(2) Journal of European Public Policy 137.

${ }^{30}$ B Crum, 'Parliamentary Accountability in Multilevel Governance: What Role for Parliaments in Post-crisis EU Economic Governance?' (2018) 25(2) Journal of European Public Policy 268; V Kreilinger, 'National parliaments, surveillance mechanisms and ownership in the euro area' (2016) Jacques Delors Institute (Berlin) Studies and Reports No. 110, www.delorsinstitut.de/2015/wp-content/uploads/2016/03/Nat.Parl_.SurveillanceOwnership -Kreilinger-JDIB-Mar16.pdf, accessed 21 October 2019.

31 S Sabato, B Vanhercke with S Spasova, 'Listened to, but not heard? Social partners' multilevel involvement in the European Semester' (2017) European Social Observatory (OSE) paper series No 35; Eurofound, Role of the Social Partners in the European Semester (Publications Office of the European Union 2016) www.eurofound.europa.eu/sites/default/ files/ef publication/field ef document/ef1570en.pdf, accessed 21 October 2019.

32 Verdun and Zeitlin (n 29).

33 Ibid. 


\subsection{Bringing Together Separate Coordination Mechanisms}

On the one hand, the employment and social OMCs, the SGP and the MIP are separate coordination mechanisms with their own sets of rules. On the other hand, they overlap and influence each other, leading to a governance mechanism with a rather hybrid character. This hybrid character includes the combination of 'soft' deliberative coordination mechanisms related to the employment strategy and social OMC, with 'hard' rule-based elements of both the SGP and the MIP. ${ }^{34}$ While rule-based governance has the image of improving compliance, coordination-based governance, or soft law, may be much better suited to dealing with complex issues in complex societies as it can set joint targets while leaving the precise policy formation to the national level. ${ }^{35}$ This also means that coordination-based governance respects the autonomy of Member States in employment and social policy. The overlap in coordination mechanisms occurs when they start dealing with the same policy domain. There is thus a thematic overlap.

There has always been a link between SGP and labour market issues. From the outset, the SGP included guidelines on 'appropriate' wage developments, meaning that wages should be in harmony with price stability and job creation. After 2011, the SGP started incorporating more links with employment policy issues, including in its recommendations. ${ }^{36}$ Topics in recommendations stemming from the SGP have included lowering taxation on labour, combating the shadow economy, improving access to health care and increasing investment in education. The MIP also shows such thematic overlap by referring to (un)employment trends and labour costs as factors influencing macroeconomic stability. Such overlaps spark debates as, in principle, they create the option to recommend policy directions for corrective action in domestic employment policy issues if the assessment entails a perceived risk of employment policies jeopardising macroeconomic stability. ${ }^{37}$ The prospect of a fine may serve as a stick for Euro area states to implement the required reforms, including in domestic employment policies. Viewing this issue from the three axes which were introduced in the previous section, one may observe how discussions on a social-economic balance are connected with discussions on the intergovernmentalsupranational balance (the use of what instrument to steer which socio-economic topics), and consequently also the technocratic-democratic balance, as each instrument has a different impact on the national room to manoeuvre.

\footnotetext{
34 KA Armstrong, 'The New Governance of EU Fiscal Discipline' (2013) 38(5) European Law Review 601; Bekker (n 19).

35 See the discussion in DM Trubek, P Cottrell and M Nance, "Soft Law," "Hard Law," and European Integration: Toward a Theory of Hybridity' (2005) Jean Monnet Working Paper No $02 / 05$.

36 S Bekker, 'Can European Socio-economic Governance Be Social Investment Proof?' in A Hemerijck (ed), The Uses of Social Investment (Oxford University Press 2017).

37 P Pecinovski, EU economic governance en het recht op collectief onderhandelen (Die Keure 2019); Bekker and Klosse (n 3).
} 
Especially in the first few years of the Semester, many countries implemented structural reforms and took austerity measures in order to reduce public expenditure. These included more labour market flexibility, cutting down expenditure on social security, or raising pension ages. ${ }^{38}$ In reality it is difficult to make a sharp distinction between social and economic domains. ${ }^{39}$ Social policies have important economic and fiscal implications and often involve public expenditure. Likewise, economic policies might have social consequences. ${ }^{40}$ This inseparability seems to contrast with the Treaty, which clearly separates different policy fields and attaches quite different EU competences to each policy field. ${ }^{41}$

However, in line with the adaptability of coordination cycles, the Semester has gradually changed to incorporate social concerns better. It is a result of early criticisms of the one-sided focus on austerity measures and structural reforms, and the call to improve the EU's social dimension in view of the severe social consequences of the crisis (for example, the 'unacceptable reality' of high youth unemployment rates). ${ }^{42}$ For instance, the Annual Growth Survey started including the fight against the negative social consequences of the crisis as of 2011. Over time, a 'socialization' of the Semester has been witnessed. ${ }^{43}$ Its social policy goals have been emphasised more and also social actors have been learning how to get involved in the process more effectively. Other initiatives aligned this 'socialization' of the Semester, for instance the Social Investment Package (2013), the Youth Guarantee and the Youth Initiative (2013). ${ }^{44}$ As of 2015, the Juncker Commission set European social policies

38 J Heyes, 'Flexicurity in Crisis: European Labour Market Policies in a Time of Austerity' (2013) 19(1) European Journal of Industrial Relations 71; C Hermann, 'Crisis, Structural Reform and the Dismantling of the European Social Model(s)' (2014) 38(1) Economic and Industrial Democracy 51; de la Porte and Heins (n 1).

39 S Bekker, 'Is there Flexibility in the European Semester Process? Exploring Interactions Between the EU and Member States Within Post-crisis Socio-economic Governance' (2016) Swedish Institute for European Policy Studies (SIEPS) Report 2016:1. See also D Schiek, 'The EU's Socio-economic Model(s) and the Crisi(e)s - Any Perspectives?' (2013) CELLS Online Paper Series No 2013: 2.

40 J Zeitlin, 'Towards a Stronger OMC in a More Social Europe 2020: A New Governance Architecture for EU Policy Coordination' in E Marlier, D Natali and R Van Dam (eds), Europe 2020: Towards a More Social EU? (Peter Lang 2010).

41 R Al-Kadi and S Clauwaert, 'Socialising the European Semester? Measuring Member States' Implementation of Country-specific Recommendations in the Social Policy Field' (2019) ETUI Working Paper No 2019/08; Bekker (n 39).

${ }^{42}$ European Commission, 'Statement by President Barroso following an informal meeting with the Social Partners' (2012) MEMO/12/33, https://europa.eu/rapid/press-release_MEMO -12-33_en.htm, accessed 21 October 2019.

${ }_{43} \mathrm{~J}$ Zeitlin and B Vanhercke, 'Socializing the European Semester: EU Social and Economic Policy Coordination in Crisis and Beyond' (2018) 25(2) Journal of European Public Policy 149.

${ }_{44}$ European Commission, 'Towards Social Investment for Growth and Cohesion' (2013) $\operatorname{COM}(2013) 83$ final; Resolution of the Council and of the Representatives of the Governments of the Member States, meeting within the Council, of 20 May 2014 on a European Union Work Plan for Youth for 2014-2015 (2014) OJ C 183; F Vandenbroucke, A Hemerijck and B Palier, 
high on the agenda, initiating the EU Pillar of Social Rights, which was proclaimed in 2017. ${ }^{45}$ The Pillar's goals have been integrated in the Semester, for instance the content of some of the recommendations reflects the Pillar's priorities. However, the tale of a gradual socialisation of the Semester is not convincing to everyone. ${ }^{46}$ Individual countries are still under strengthened scrutiny in the corrective arms of the SGP. In 2018, two countries experienced excessive deficits under the corrective arm of the SGP (France and Spain). In the same year, 12 countries were part of an in-depth review of the MIP, of which three were found to have excessive imbalances (Cyprus, Croatia and Italy). ${ }^{47}$ As such, the mutual influence of coordination mechanisms on other policy domains remains relevant also after the crisis. Legal scholars therefore keep researching the impact of stricter EU economic governance on the social domain. ${ }^{48}$ A related line of research focuses on the effectiveness of the Semester. Although there seems to be a certain relief among some groups of scholars that stricter economic recommendations do not necessarily always lead to reforms on the national level, this non-automatic compliance is also valid for recommendations that do support social goals. This deficiency of social recommendations to influence national practices raises questions on whether the Semester is the correct tool to implement the goals of the European Pillar of Social Rights. ${ }^{49}$ These questions show the continuous relevance of studying the Semester, from the perspective of a socio-economic axis and from that of a mix of hard and soft law, taking due account of these being intertwined. ${ }^{50}$ The next section develops the axis of intergovernmentalism versus supranationalism.

'The EU Needs a Social Investment Pact', European Social Observatory (OSE) Paper Series (2011) Opinion paper No. 5.

45 See also the chapters by Zahn and Alexandris Polomarkakis in this volume.

46 For example, P Copeland and M Daly, 'The European Semester and EU Social Policy' (2018) 56(5) JCMS: Journal of Common Market Studies 1001; A Crespy and G Menz, 'Commission Entrepreneurship and the Debasing of Social Europe Before and After the Eurocrisis' (2015) 53(4) JCMS: Journal of Common Market Studies 753; de la Porte and Heins (n 1).

47 Moreover, in 2018, Greece was still outside the Semester coordination as it fell within the specific programme of countries having signed a Memorandum of Understanding. This situation changed in the autumn of 2018, incorporating Greece fully into the European Semester of 2019 for the first time. See European Commission, '2018 European Semester: Assessment of progress on structural reforms, prevention and correction of macroeconomic imbalances, and results of in-depth reviews under Regulation (EU) No 1176/2011' (2018) COM(2018) 120 final.

48 S Garben, 'Competence Creep Revisited' (2019) 57(2) JCMS: Journal of Common Market Studies 205; M Dawson, 'New Governance and the Displacement of Social Europe: The Case of the European Semester' (2018) 14(1) European Constitutional Law Review 191; N Büttgen, EU Employment Governance Revisited: Towards an Innovative Legal Framework for Employment Regulation (Datawyse 2017); Armstrong (n 34).

49 Al-Kadi and Clauwaert (n 41).

50 Verdun and Zeitlin (n 29). 


\section{DIVISION OF TASKS BETWEEN THE EU AND THE MEMBER STATES}

The discussion on the use of coordination-based or rule-based steering is in essence also a discussion on the division of competences between the EU and the national levels. Also as regards this 'intergovernmental-supranational' axis, complexity supersedes simple polar oppositions. ${ }^{51}$ Actually, the Semester may very well be an excellent case of multilevel governance as it involves the dynamic interaction of EU-level and national-level actors. ${ }^{52}$

In order to study the division of tasks between the EU and the Member States in combination with dynamic actor interaction, Scharpf uses a combination of different theories to understand processes within a multilevel governance setting. ${ }^{53}$ These concern the different modes of governance that give the EU and national-level authorities different degrees of autonomy (see also Vanhercke, who also uses different theoretical lenses to explore the social OMC). ${ }^{54}$ Scharpf distinguishes four modes of multilevel interaction: mutual adjustment, intergovernmental negotiations, joint decision and hierarchical direction. ${ }^{55}$ Mutual adjustment refers to national governments making their own policies at national level, albeit not in isolation. They develop their policies in response to, or in anticipation of, the policies made by other governments. Intergovernmental negotiation is the lowest level of institutionalisation, with national governments agreeing to coordinate or standardise national policies at the EU level. National governments remain in full control of the decision-making process. ${ }^{56}$ The joint decision mode combines elements of intergovernmental negotiation and supranational centralisation, and comes closest to the classic way of EU law-making: the Commission proposes a law, the European Parliament and the Council have co-decision rights, while the final decision is taken by the Council. Lastly, hierarchical direction centralises competencies completely to the EU-level and supranational actors. In this mode, the national governments do not participate. Also, Schmidt differentiates between intergovernmentalism, supranationalism and parliamentarism, and urges that these theories be adjusted to the reality of 'new' EU governance, which includes dynamic interactions among EU actors. ${ }^{57}$ Taking this background to view the Semester, the type of coordination mechanisms

51 Ibid.

52 VA Schmidt, "Rethinking EU Governance: From "Old" to "New" Approaches to Who Steers Integration’ (2018) 56(7) JCMS: Journal of Common Market Studies 1544; J Zeitlin, 'EU Experimentalist Governance in Times of Crisis' (2016) 39(5) West European Politics 1073. See also the chapters by Cardwell and Gaglia Bareli in this volume.

53 FW Scharpf, 'Notes Toward a Theory of Multilevel Governing in Europe' (2002) 24(1) Scandinavian Political Studies 1.

54 BWR Vanhercke, 'Inside the Social Open Method of Coordination: The Hard Politics of "Soft" Governance' (PhD thesis, University of Amsterdam 2016).

55 Scharpf (n 53).

56 Ibid.

57 Schmidt (n 52). 
used to address an issue, as well as the progress a Member State has made in the corrective arm of the SGP or MIP, may be relevant to understand the setting in which actors across governance levels engage in dynamic interactions. Then still, careful scrutiny seems needed to explain the outcome of all the coordination exercises, since politically driven implementation and enforcement shortcomings, for instance, may play a role as well. ${ }^{58}$

Zeitlin has a suggestion for a methodology to carefully scrutinise the complexities of the Semester: the process-tracing method. This method not only builds on very rich empirical evidence, but also is able to uncover a sequence of events, or certain causality. This way, the sequence of events, including the order and structure of dynamic interactions of actors across levels, could be mapped out. Exercises using the method may be found in Bekker when studying the making of the EU flexicurity concept, adding also the congruence method, which benefits from some theoretical guidance. $^{59}$

Dynamic interactions of EU-level and national-level actors may be observed at several points in the Semester's coordination cycle, when actors meet to negotiate targets, recommendations and the timing of reforms.$^{60}$ For instance, representatives of the European Commission meet national governments during bilateral meetings or fact-finding missions. ${ }^{61}$ Also the Committees such as EMCO and SPC are relevant as they consist of representatives of each Member State and are chaired by the Commission. Here, discussions on the socio-economic status of and recommendations to countries take place. Similar committees exist for discussing economic and fiscal concerns. Taking into consideration such dynamic interactions in a multilevel governance setting is of key importance when trying to understand how the Semester operates. For instance, there could be 'feedback loops' from the national to the EU level, ${ }^{62}$ thus feeding or influencing the Commission's evaluation of a country. Similarly, countries tend to have a degree of freedom in picking out certain reforms, contesting less sensible recommendations or disagreeing on calculation methods that underpin a recommendation. ${ }^{63}$ National instruments, resources and willingness

58 Begg (n 2)

59 Bekker (n 14); AL George and A Bennett, Case Studies and Theory Development in the Social Sciences (MIT Press 2005).

60 A Maricut and U Puetter, 'Deciding on the European Semester: the European Council, the Council and the Enduring Asymmetry Between Economic and Social Policy Issues' (2018) 25(2) Journal of European Public Policy 193; Zeitlin and Vanhercke (n 43).

${ }^{61}$ M Munta, 'Building National Ownership of the European Semester: The Role of European Semester Officers' (2020) 21(1) European Politics and Society 36; Zeitlin and Vanhercke (n 43).

${ }^{62}$ S Saurugger, 'Europeanisation in Times of Crisis' (2014) 12(2) Political Studies Review 181.

63 Bekker (n 26); E Eihmanis, 'Cherry-picking External Constraints: Latvia and EU Economic Governance, 2008-2014' (2018) 25(2) Journal of European Public Policy 231; C Louvaris Fasois, 'Mechanisms of Policy Learning in the European Semester: Pension Reforms in Belgium' in C Dunlop, C Radaelli and P Trein (eds), Learning in Public Policy (Palgrave Macmillan 2018). 
might play a role in implementing EU policies, irrespective of the way in which these policies are communicated: through soft law, Directives or case law of the Court of Justice. ${ }^{64}$ Also national politics may be a decisive factor, thus influencing the output and outcomes of implementation. ${ }^{65}$ Moreover random factors may play a role, for example the 'personal factor' and 'satisficing logics of action' ${ }^{66}$ Relevant is the role not only of the national governments, but also the national parliaments ${ }^{67}$ and the national and social partners. ${ }^{68}$ Likewise, the role of the European Parliament and EU-level social partners is an element that should be taken into account. Here, adjustments to the process have been made and also the EU Pillar of Social Rights emphasises the need to stimulate social dialogue. Over time, more space has been given to bilateral and multilateral debate, incorporating a larger group of actors. ${ }^{69}$ In theory, coordination-based governance enables such participation of actors in various stages of policy or law formation, ${ }^{70}$ yet Scharpf also shows different combinations of EU and national prerogatives to make (co-)decisions. ${ }^{71}$

Overall, there does not seem to be a clear actors or governance level on the steering wheel of the Semester. Although the European Commission has a large role in the process, it cannot exercise its powers and capacities without the national actors. ${ }^{72}$ What could be a next step is empowering and encouraging national actors, especially the national social partners, but also the national parliaments, to play a more convincing role in the Semester process. ${ }^{73}$ The inclusion of actors, notably the national parliaments, also refers to discussion along the axis of technocratic steering versus democratic decision making. ${ }^{74}$ It is the discussion on moving decision making to unelected and difficult-to-check technocrats, instead of giving democratic institutions such as parliaments the responsibility to decide on policy reforms. ${ }^{75}$ Here, a link may

${ }^{64}$ DS Martinsen and H Vollaard, 'Implementing Social Europe in Times of Crises: Re-established Boundaries of Welfare?' (2014) 37(4) West European Politics 677.

65 Eihmanis (n 63).

${ }_{66}$ M Ferrera, 'Social Europe and its Components in the Midst of the Crisis: A Conclusion' (2014) 37(4) West European Politics 825.

${ }_{67}$ Crum (n 30); M Hallerberg, B Marzinotto and GB Wolff, 'Explaining the Evolving Role of National Parliaments under the European Semester' (2018) 25(2) Journal of European Public Policy 250.

${ }^{68}$ I Guardiancich and O Molina (eds), Talking Through the Crisis: Social Dialogue and Industrial Relations Trends in Selected EU Countries (International Labour Organization 2017); Sabato, Vanhercke with Spasova (n 31).

${ }^{69}$ Verdun and Zeitlin (n 29).

70 B Eberlein and D Kerwer, 'New Governance in the European Union: A Theoretical Perspective' (2004) 42(1) JCMS: Journal of Common Market Studies 121; J Mosher and D Trubek, 'Alternative Approaches to Governance in the EU: EU Social Policy and the European Employment Strategy’ (2003) 41(1) JCMS: Journal of Common Market Studies 63.

${ }_{71}$ Scharpf (n 53).

72 Verdun and Zeitlin (n 29).

73 Ibid; Ferrera (n 66).

74 Verdun and Zeitlin (n 29).

75 VA Schmidt, "The Forgotten Problem of Democratic Legitimacy "Governing by the Rules" and "Ruling by the Numbers"' in M Matthijs and M Blyth (eds), The Future of the Euro 
also be made to studying the effectiveness of the Semester. In essence, one could ask the question whether the Semester is effective if a country simply implements the recommendation that was given. Or is the Semester effective if it manages to create informed debates among actors about key challenges and the appropriate solutions in terms of policy reforms?

\section{CONCLUSIONS}

As the Semester is still a work in progress, each year brings new opportunities to shift the balances on each of the three axes: the balance between social and economic policies; the balance between national and EU-level prerogatives; and the technocratic and democratic aspects. However, the complexity of the Semester makes it quite useless to make simple conclusions that make a general statement on the Semester being a static case of only supporting economic goals, or only being a supranational vehicle. For example, studies of the Semester show that goals and recommendations can support economic as well as social policies at the same time, while showing variety over time and across countries. ${ }^{76}$ Similar conclusions may be drawn when focusing the study of the Semester across the axes of the national and EU-level prerogatives; and the technocratic and democratic aspects. It means that scholars should choose to conduct in-depth studies. They should search for combinations of different theoretical and methodological techniques, which could be informed by several academic disciplines. ${ }^{77}$ Such careful research is not always easy, but it is useful and potentially a lot of fun. Questions that could be researched may include the effectiveness of the Semester, the role and inclusion of the (European) social partners, the way the European Pillar of Social Rights may be implemented using the Semester, or - taking a wider discussion - what, how and why the notion of a European Social Union could be developed further. Another interesting line of research is the role of the European Social Funds, especially now that the finances they provide have been related more to the implementation of the country-specific recommendations.

(Oxford University Press 2015); FW Scharpf, 'After the Crash: A Perspective on Multilevel European Democracy’ (2014) MPIfG Discussion Paper No 14/21.

76 Bekker (n 14).

77 F Vandenbroucke, C Barnard and G De Baere (eds), A European Social Union After the Crisis (Cambridge University Press 2017). 